\title{
Retinal Examination
}

National Cancer Institute

\section{Source}

National Cancer Institute. Retinal Examination. NCI Thesaurus. Code C101217.

An examination of the retina of the eye using an ophthalmoscope. 